
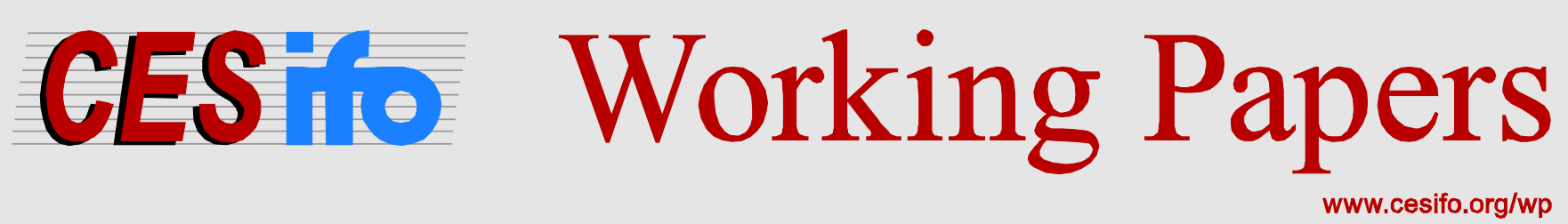

\title{
Euro-Area Fiscal Stance: From Theory to Practical Implementation
}

\author{
Agnès Bénassy-Quéré
}

\author{
CESIFO WORKING PAPER NO. 6040 \\ CATEgory 6: Fiscal Policy, MaCroeconomics AND GROWTH \\ August 2016
}

An electronic version of the paper may be downloaded

- from the SSRN website: Www.SSRN.com

- from the RePEc website: Www.RePEc.org

- from the CESifo website: www.CESifo-group.org/wp 


\title{
Euro-Area Fiscal Stance: From Theory to Practical Implementation
}

\begin{abstract}
Despite large automatic stabilizers, the performance of the Euro area as a whole in terms of fiscal stabilization is relatively poor. This report argues that a meaningful fiscal stance for the Euro area should rely on the current account as a complement to the output gap, and be coordinated only in "exceptional" times, the usual bottom-up approach of fiscal policy remaining appropriate for "normal" times. In such setting, the European Fiscal Board would play a key role in advising the Commission on the existence of "exceptional" circumstances, on the adequate aggregate fiscal stance and on its desirable distribution across member states.
\end{abstract}

JEL-Codes: E620, F420, F450.

Keywords: fiscal stance, coordination of fiscal policies, euro area, European Fiscal Board.

\author{
Agnès Bénassy-Quéré \\ Paris School of Economics \\ University Paris 1 Panthéon-Sorbonne \\ Paris / France \\ agnes.benassy@univ-paris1.fr
}

July 2016

This paper was initially requested by the European Parliament's Economic and Monetary Affairs Committee for the Economic Dialogue with the President of the Eurogroup. The opinions expressed in this paper are the sole responsibility of the author and do not necessarily represent the official position of the European Parliament. The original paper is available on www.europarl.europa.eu/RegData/etudes/IDAN/2016/574424/IPOL_IDA(2016)574424_EN.pdf Copyright remains with the European Union. Research assistance from Paul Berenberg-Gossler is gratefully acknowledged. 


\section{INTRODUCTION}

The organisation of fiscal policy in the euro area has evolved over time along a trial-and-error process, with three successive building blocks:

- The initial Stability and Growth Pact (SGP) aimed at insuring that each national budget remains sustainable. The objective of the SGP was to avoid the monetary union to be destabilized by a sovereign debt crisis in one Member state (see Eichengreen and Wyplosz, 1998);

- The successive revisions of the SGP lead to focusing more on the structural (or cyclicallyadjusted) fiscal balance and introducing more flexibility in the implementation of the rules. The objective there was both to reduce the inclination of governments to carry out pro-cyclical policies, and to provide incentives for structural reforms;

- The introduction of national fiscal councils aimed at raising national ownership of fiscal rules and providing an independent assessment of their implementation by experts that are more familiar to national specificities. This innovation is consistent with the academic literature showing that fiscal councils are complement to fiscal rules and that they do help to mitigate the deficit bias of national governments (Calmfors and Wren Lewis, 2011; Beetsma and Debrun, 2016).

In June 2015, the Five President's report noted that "all mature Monetary Unions have put in place a common macroeconomic stabilisation function to better deal with shocks that cannot be managed at the national level alone" (p. 14). It subsequently proposed to "improve the cushioning of large macroeconomic shocks and thereby make EMU overall more resilient". In the short run, an advisory European Fiscal Board (EFB) would be introduced with the task to both coordinate the implementation of the SGP at national level, and produce an independent, euro-wide view of fiscal policy.

In October 2015, the European Commission issued its decision concerning the establishment of the EFB, which will be given four tasks: (i) provide to the Commission an evaluation of the implementation of fiscal rules and of the appropriateness of the actual "fiscal stance" at euro area and national level; (ii) advise the Commission on the appropriate fiscal stance for the euro area as a whole, (ii) cooperate with national fiscal councils, and (iv) on request of the President, provide ad-hoc advice. One underlying objective is to better coordinate national fiscal policies in case the euro area is hit by a large shock that cannot be cushioned by monetary policy alone.

In existing federal countries, regional fiscal policies are not coordinated, but nationwide shocks can be mitigated by the federal budget, with an increase in the federal deficit in case of a downturn and fiscal adjustment in case of an upturn. Federal budgets have other objectives than just macroeconomic stabilization: they also produce public goods and services that are useful for the whole federation (e.g. internal and external security, a federal court of justice, etc.), and they carry out transfers across regions in order to correct for geographic or historical inequalities.

In the euro area, since there is no federal budget, ${ }^{1}$ the only way to carry out an aggregate policy is through coordinating national fiscal policies. In a sense, fiscal coordination is a way to mimic what a federal fiscal policy could deliver. It is reminiscent of the European Monetary System (EMS) whose purpose before 1999 was to mimic an aggregate monetary policy through coordinating national monetary policies around fixed exchange rates. ${ }^{2}$ The experience of the EMS, as well as international experiences $(\mathrm{G} 7, \mathrm{G} 20)$ suggest that coordination is fragile. In the case of monetary policy, however,

\footnotetext{
${ }^{1}$ The European Stability Mechanism (ESM) cannot be considered as an equivalent to a federal budget. It is a mutual assistance scheme that may help national governments to limit the pro-cyclicality of their policies in case of a crisis.

${ }^{2}$ Although in practice the EMS amounted to an alignment of monetary policies on Germany, not on the region as a whole.
} 
it has proved useful as a step towards further integration. Likewise, a European Fiscal System (EFS) could be a useful step towards some form of fiscal integration.

In section 2 we raise the issue of an aggregate fiscal stance based on simple theory and some stylised facts. In section 3, we provide some thoughts on how to operationalise the idea of an aggregate fiscal stance for the euro area. Section 4 discusses the governance of a euro area fiscal stance.

\section{FISCAL STABILIZATION IN A LARGE ECONOMY}

\subsection{Is the euro area a large economy?}

In 2015, the euro area represented $16 \%$ of world GDP, while the United States weighed $22 \%$. In 2030, under reasonable assumptions, the euro area could represent $12 \%$ of world GDP, and the United States $16 \%$. Although it will remain smaller than that of the United States, the economic weight of the euro cannot be considered negligible. During the same period, the share of the United Kingdom could fall from $3.6 \%$ to $3.2 \%$, and that of the largest euro area country - Germany - from $4.7 \%$ to $2.9 \%$. $^{3}$

As for trade openness, the share of exports and imports in GDP is similar in the euro area (18\% excluding intra-euro area flows) and the United States (14\%), whereas it amounts to 52\% for Germany. ${ }^{4}$

Hence, from a macroeconomic point of view, the euro area is a "large" economy in the sense that (i) the policy decisions taken by the euro area are significant enough to affect the rest of the world, and (ii) the "leakage" of fiscal policy through imports is limited at aggregate level.

What is really different in the euro area, compared to the United States, is the absence of a federal budget, combined with a large amount of regional public debt:

- In the United States, the sum of gross state and local public debt, in terms of state GDP, ranges from $2.7 \%$ (Wyoming) to $24.9 \%$ (New York); ${ }^{5}$

- In the euro area, the gross public debt ratio of Member states ranges from $9.7 \%$ of GDP (Estonia) to $176.9 \%$ (Greece) ${ }^{6}$

The total debt ratio is comparable in the euro area $(92.9 \%)$ and in the United States $(101.9 \%)$. However the distribution is different, with virtually all the debt being at member state level in the euro area whereas most debt is at federal level in the United States. ${ }^{7}$

Hence, the euro area is a "large" economy in a macroeconomic sense, yet is a "small" economy in a financial sense: the debt is issued separately by each Member state in a currency that is "foreign" to the extent that national central banks cannot print it independently from the Eurosystem. This makes fiscal policy more vulnerable to market reversals and self-fulfilling prophecies (see De Grauwe and Ji, 2013).

\footnotetext{
${ }^{3}$ All these projections in current USD are taken from Econmap 2050, January 2016 release, available at www.cepii.fr.

${ }^{4}$ Sources: Eurostat and Federal Reserve Board of St Louis.

${ }^{5}$ Source: www.usgovernmentspending.com, fiscal year 2016.

${ }^{6}$ Source: Ameco at end 2015.

${ }^{7}$ The debts of the European Union, European Investment Bank, European Financial Stability Facility, European Stability Mechanism together represent EUR bn 561, i.e. 5.4\% euro area's GDP, see Claeys et al (2015).
} 

cannot involve uniform fiscal policies: some differentiation is required across Member states, even when the euro area is hit by a symmetric shock. ${ }^{8}$

\subsection{Some useful theory}

\subsubsection{The (cross-) Keynesian multiplier in an open economy}

The basic theory of macroeconomic stabilization in an open economy (the Mundell-Fleming model) yields the following two results for the euro area:

- At the level of each member state, to the extent that government debt remains sustainable, fiscal policy is able to cushion specific demand shocks. The reason is that there is limited crowding out: the interest rate, which in normal times is similar across member states, does not rise much in case the dedicit of one of them increases; nor does its exchange rate appreciate much. Of course, the Keynesian multiplier differs across countries, notably due to differing openess ratios.

- At the level of the euro area, a fiscal stimulus will involve some crowding out both through the interest rate (which will rise, hence reducing private spending) and through the exchange rate (which will appreciate, hence curbing net foreign demand). However, since the euro area is a "large" economy in a macroeconomic sense, there is only partial crowding out. Additionally, at the zero lower bound (ZLB), the interest rate is not expected to increase following fiscal stimulus nor to fall following fiscal contraction.

As for fiscal spillovers across member states, we get the following results:

- In normal times, the net effect of fiscal stimulus in one member state A on another member state B is ambiguous: on the one hand, higher demand in A stimulates exports from B to A; on the other hand, higher demand in A will make the common monetary policy more restrictive or less expansionary, triggering a higher interest rate and an exchange-rate appreciation for both countries.

- At the ZLB, the second channel is disactivated, so fiscal spillovers are unambiguously positive, although their size depends on trade integration.

\subsubsection{Relative price adjustments}

An obvious limitation of the Keynesian multiplier is the state of the economy. If the economy displays excess supply over demand, then stimulating demand will result in a higher volume of GDP. Alternatively, if the economy initially displays excess demand, more demand will only raise the level of prices. In case of a fiscal contraction, GDP will fall only if there is excess supply in the economy; if there is excess demand, only prices will fall (or increase less).

This basic observation bears two important consequences for the euro area:

- Fiscal policy can have an impact on prices both at the member state level and at the aggregate level.

- Fiscal spillovers across countries are channelled not only through income effects, but also through relative prices: in an environment of low inflation, stimulating an economy that is already at full employment may have positive spillovers on other countries if it helps them achieving needed relative price adjustment without falling in deflation.

\footnotetext{
${ }^{8}$ A symmetric shock hits each member state in a similar way; and asymmetric shock hits the member states in different ways.
} 


\subsubsection{Empirical results}

There is a large body of literature on estimation of the Keynesian multiplier. The literature on crosscountry multipliers is however more limited.

Using different multi-country models, Cwik and Wieland (2010) find relatively small fiscal spillovers. Spillovers within the euro area may even turn out negative due to the impact of fiscal stimulus on the euro exchange rate. However, using an econometric specification that aggregates foreign unanticipated fiscal shocks, Auerbach and Gorodnichenko (2010) show fiscal spillovers to differ widely between expansions (where they are negligible) and recessions (where they are large and significant). In turn, based on the "narrative approcach" of fiscal consolidation, Goujard (2016) shows that the spillovers are large for synchronised fiscal consolidations, especially in a monetary union. Relying on a GVAR estimation, Hebous and Zimmermann (2013) also find that a synchronised fiscal consolidation in neighbouring countries has a strong impact on GDP. By simulating the Commission's QUEST model, In't Veld also finds strong fiscal spillovers during the European 201113 consolidation period.

When the interest-rate channel is no longer active, fiscal spillovers become more powerful. This is the result found by Beetsma et al. (2006) who focus on trade spillovers within the European Union, and more recently by Blanchard et al. (2015) who study fiscal spillovers at the ZLB.

From this short literature survey, we conclude that, in "normal times", fiscal spillovers are limited across euro area member states. In "exceptional times", however, they become very significant. Following the literature, "exceptional times" may cover years of recession, of synchronised consolidation, or when monetary policy is constrained by the ZLB.

\subsection{Measurement issues}

The orientation of fiscal policy is generally captured through the concept of "fiscal stance". The fiscal stance is routinely measured through the variation of the structural balance. The structural balance is the overall balance (or net lending) of the general government corrected for the impact of the economic cycle and one-off items. These corrections aim at focusing on the "voluntary" impulse given by fiscal authorities, i.e. discretionary decisions on taxes and spending. The rest of deficit variation is labelled "automatic" since in principle it results from applying a fixed tax schedule to varying income. ${ }^{9}$ The distinction between discretionary and automatic fical policies is sometimes applied to the primary balance rather than the financial one since interest payments are considered to be largely beyond the reach of government decision.

The calculation of the structural balance raises many issues. The main ones are (i) the calculation of potential GDP and the output gap, (ii) the elasticity of the budget balance to the output gap, and (iii) the impact of inflation. Here we illustrate each of these problems in turn.

\subsubsection{The measurement of potential output}

The measurement of potential output may rely on the estimation of a production function or purely on statistical methods. In both cases, the measurement relies on past evolutions, so it is unfitted to predict major inflections. Figure 1 illustrates this feature for the euro area. Between its June 2008 and June 2016 forecasts, the OECD revised the level of potential output in the euro area by 5 percentage points downwards.

\footnotetext{
${ }^{9}$ Because tax receipts are closely related to GDP whereas public spending is not, the budget balance is expected to improve in good times and deteriorate in bad times.
} 
Figure 1: Euro area's potential output revisions

(100 in 1995)

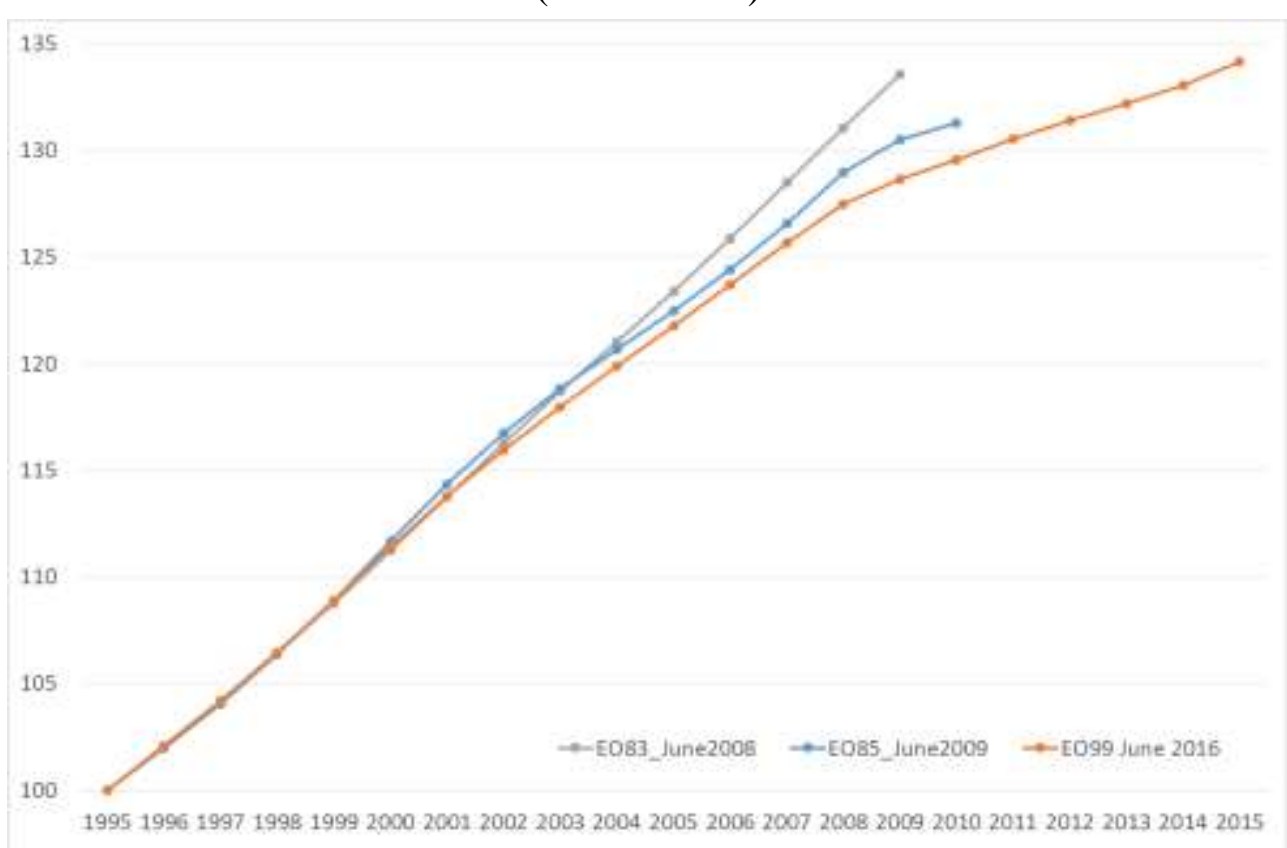

Source: OECD and author's calculations.

The impact of the Global economic crisis on potential growth has been widely debated. The recent consensus view seems to be that of a reduced growth in advanced economies: although the specific impact of the crisis itself will progressively fade away, population ageing will maintain a drag on potential growth (see, e.g., IMF, 2015a). Furthermore, some scholars (Gordon, 2012) argue that productivity growth has come back to a "normal", lower pace, whereas others (Summers, 2014) point the lack of aggregate demand at global level as the main cause of forthcoming "secular stagnation", since the interest rate that would equalize supply and demand is well below zero (see the debate on "secular stagnation" in Teulings and Baldwin, eds., 2014.

\subsubsection{The elasticity of budget balance to the output gap}

The second problem raised by the calculation of the structural deficit is that of the elasticity of the budget balance to the output gap. Ideally, each tax and expenditure elasticity should be calculated separately and then aggregated. Since this is not possible in a consistent way for a large panel of countries, the approach generally taken is to calculate the elasticity directly at aggregate level. However the result is an imperfect correction for the cycle, as evidenced in Figure 2 for the euro area. The cyclical part of the overall budget balance closely follows the output gap, but the relationship between the two variables is not stable. In 2006, for instance, the increase in the cyclical balance is less marked than that of the output gap; part of the fiscal adjustment is then attributed to structural adjustment. ${ }^{10}$ The reverse can be observed in 2013: the cyclical balance falls less than the output gap, which amounts to minoring the structural adjustment that particular year.

Additionally, the output gap only captures the real part of the economic cycle. Asset price bubbles may have an impact on public finances even without showing up in the output gap. For instance, property taxes increased by 1.2 percent of GDP in Ireland between 2002 and 2006, while according to the OECD the output gap was similar in both years. ${ }^{11}$

\footnotetext{
${ }^{10}$ Using the following identity: $\frac{\text { overall balance }}{G D P}=\frac{\text { underlying balance }}{\text { Potential GDP }} \times \frac{\text { Potential GDP }}{G D P}+\frac{\text { cyclical balance }}{G D P}$, we can see that, for a given consolidation of the overall balance, less adjustment of the cyclical balance means either more structural adjustment, or a fall in the ratio of potential to effective GDP combined with a negative underlying balance. In 2006, according to the OECD, the aggregate structural adjustment was of 0.28 percent of potential GDP, whereas the effect of the variation of potential to effective GDP was 0.04 percent.

${ }^{11}$ For more discussion on the elasticity of the budget to the output gap, see Carnot and Castro (2015).
} 
Figure 2: A decomposition of government overall balance for the euro area

(\% of potential or observed output)*

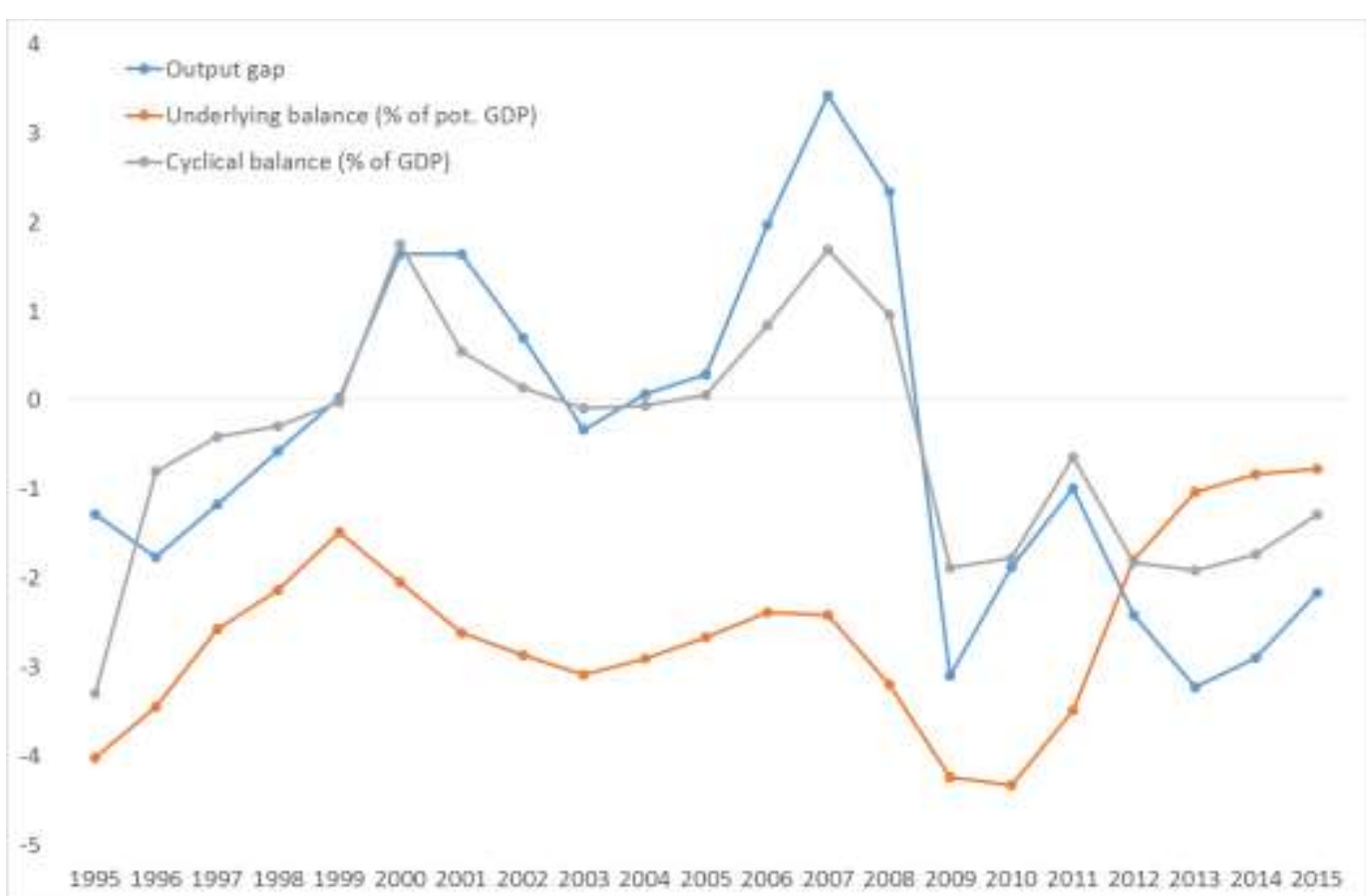

* The underlying balance is equivalent to the structural balance. The cyclical balance ratio is calculated based on the following identity: $\frac{\text { overall balance }}{G D P}=\frac{\text { underlying balance }}{\text { Potential GDP }} \times \frac{\text { Potential GDP }}{G D P}+\frac{\text { cyclical balance }}{G D P}$.

Source: OECD Economic Outlook No. 99, June 2016, and author's calculations.

In Figure 2, the structural balance (or underlying balance) tends to be correlated with the output gap, albeit only losely and with major exceptions (1996, 2000, 2010, 2012-13). The literature on fiscal stabilisation makes the distinction between descretionary reactions to the business cycle, and the "exogenous" part of structural balance variations that may cover exceptional consolidation efforts, the electoral cycle, or any fiscal decision unrelated with the stabilization objective (see Debrun and Kapoor, 2010). We come back to this issue in Section 3. Clearly, the distinction between "automatic" and "descretionary" reaction to the cycle heavily relies on the measurement of the output gap and of the elasticity of the fiscal balance to the output gap.

\subsubsection{The impact of inflation}

Inflation would be neutral if all taxes and expenditures were perfectly indexed on prices: higher prices would inflate the value of the deficit and of GDP in the same proportions, leaving the deficit-to-GDP ratio unchanged.

In practice, public expenditures tend to be only partially indexed on prices (at least in the short run) whereas tax receipts are almost perfectly indexed. ${ }^{12}$ As a result, an unexpected increase in inflation tends to improve the budget balance, whereas an unexpected fall in inflation worsens the budget balance.

Since inflation turns out especially difficult to predict (see infra), inflation adds another noise to the design of a stabilizing fiscal policy.

\footnotetext{
${ }^{12}$ See Perotti (2005). While government purchases of goods and services as well as interest payments are indexed on inflation, public wages react with a delay. On the revenue side, only specific taxes (such as excise duties or energy taxes) are not indexed on prices.
} 


\subsection{Fiscal stabilization in practice}

Here we measure the extent of fiscal counter- or pro-cyclicality in different OECD countries and for the euro area aggregate. We successively rely on the "fiscal stance" (i.e. the variation in the structural balance) and on the "fiscal adjustment" (the variation in the overall balance). A positive correlation of either the fiscal stance or the fiscal adjustment with the output gap means fiscal tightening when the output gap is high, i.e. in good times, and fiscal stimulus when the output gap is low, i.e. in bad times. Hence, a positive correlation with the output gap points to fiscal counter-cyclicality, which is stabilizing for the economy. ${ }^{13,14}$

Figure 3 shows that the fiscal stance is rarely counter-cyclical in large OECD countries, especially before the Great financial crisis. Compared to the OECD aggregate, however, the euro area (with 15 countries) performs relatively poorly, alongside Australia, Canada and the United Kingdom: the fiscal stance appears strongly pro-cyclical. In the euro area, thanks to the relatively large share of the public sector in the economy, the strong pro-cyclicality of the fiscal stance is erased by large automatic stabilizers: the overall balance is neutral in the sense that it does not react to the economic cycle, on average. Although it is better than pro-cyclicality observed in Australia, Canada and the UK, the euro area aggregate fiscal policy is less stabilizing than that of the OECD aggregate.

Figure 3: Different measures of fiscal counter-cyclicality

(Correlations with the output gap)

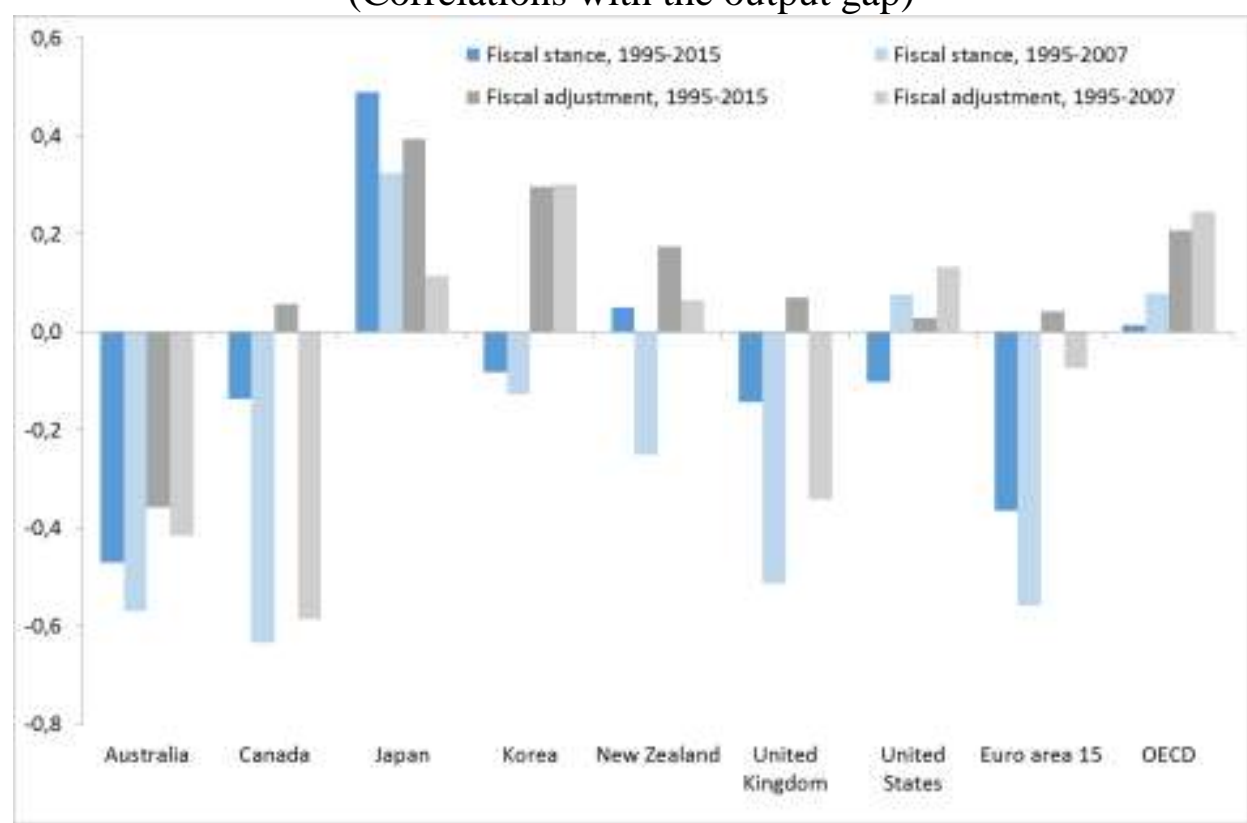

Reading: in Australia, the correlation between the fiscal stance and the output gap over 1995-2015 is -0.47. Source: OECD EO99, June 2016, and author's calculations.

The pro-cyclicality of the euro area's aggregate fiscal policy does not date back to the global financial crisis: over 1995-2007, it turns out to be more pro-cyclical than over 1995-2015. These results are consistent with the IMF (2015b) which calculates a "stabilization coefficient" as the variation of the overall fiscal balance that is associated to a $1 \mathrm{pp}$ change in the output gap, for 85 countries over 19702013 (or less, depending on data availability). Correcting for the endogeneity of the output gap through an instrumental variable technique, the IMF finds a stabilization coefficient of 0.545 for

\footnotetext{
${ }^{13}$ To the extent that the output gap reacts negatively to fiscal tightening, the correlation is biased downwards, and more so for countries displaying a high multiplier.

${ }^{14}$ Fiscal stabilization can also be assessed based on the correlation between fiscal stance or adjustment and the variation in the output gap. However the standard Keynesian model would not advise stopping the adjustment effort when the output gap moves, say, from $+3 \%$ to $+2 \%$; symmetrically, it would not advise starting to consolidate when the output gap moves from $-3 \%$ to $-2 \%$. We however mention the results obtained with output-gap variations in the text. Turrini (2008) uses both concepts which he labels "procyclicality at the margin" and "procyclicality on average".
} 
Germany, 0.842 for France, an insignificant value for Italy, and 1.055 for Spain, against 0.903 for the United States and 0.912 for Japan. More importantly, the stabilisation coefficient increases dramatically over time for the United States and Japan, but not for the four largest euro area countries.

Interestingly, the IMF (2015b) shows that, although automatic stabilizers work equally in good times as in bad, discretionary fiscal stabilization is "virtually absent" in good times. For euro-area countries, Turrini (2008) finds a pro-cyclical bias of the fiscal stance in good times, which is driven by the expenditure side of the budget.

We conclude from this section that the euro area performs relatively poorly in terms of fiscal stabilization despite relatively large automatic stabilizers, and that the problem lies especially on the expenditure side and in good times.

The question then is how to make the euro area aggregate fiscal policy more stabilizing while ensuring its sustainability in the long term.

\section{HOW TO DESIGN A MEANINGFUL FISCAL STANCE}

\subsection{The fiscal stance and the output gap}

Pro-cyclicality of the fiscal stance does not necessarily mean that national governments decide to expand the deficit in good times and reduce it in bad times. In fact, budget plans are decided in year $t$-1 for year $t$, based on existing one-year ahead economic forecasts in $t$-1. GDP is subsequently revised in $t$ and $t+1$, and the final figure is disclosed only in $t+2$.

Figure 4 illustrates the difficulty in producing accurate forecasts. It compares two measures of GDP growth for the euro area between 2004 and 2014. "Real time" GDP growth is the Commission's forecast of GDP growth made in Spring $t$-1 for year $t$. It is compared to "final" GDP growth, that is measured in Spring $t+2$. Over 2008-2014, the root-mean square error is 0.64 percentage points, almost equal to the average "final" growth rate, which is $0.7 \%$ per year. ${ }^{15}$

\footnotetext{
${ }^{15}$ Fioramanti et al. (2016) report similar errors for the one year-ahead forecast of GDP growth over a much longer period (1969-2014).
} 
Figure 4: Real time and final GDP growth rates in the euro area

(Percent per year)

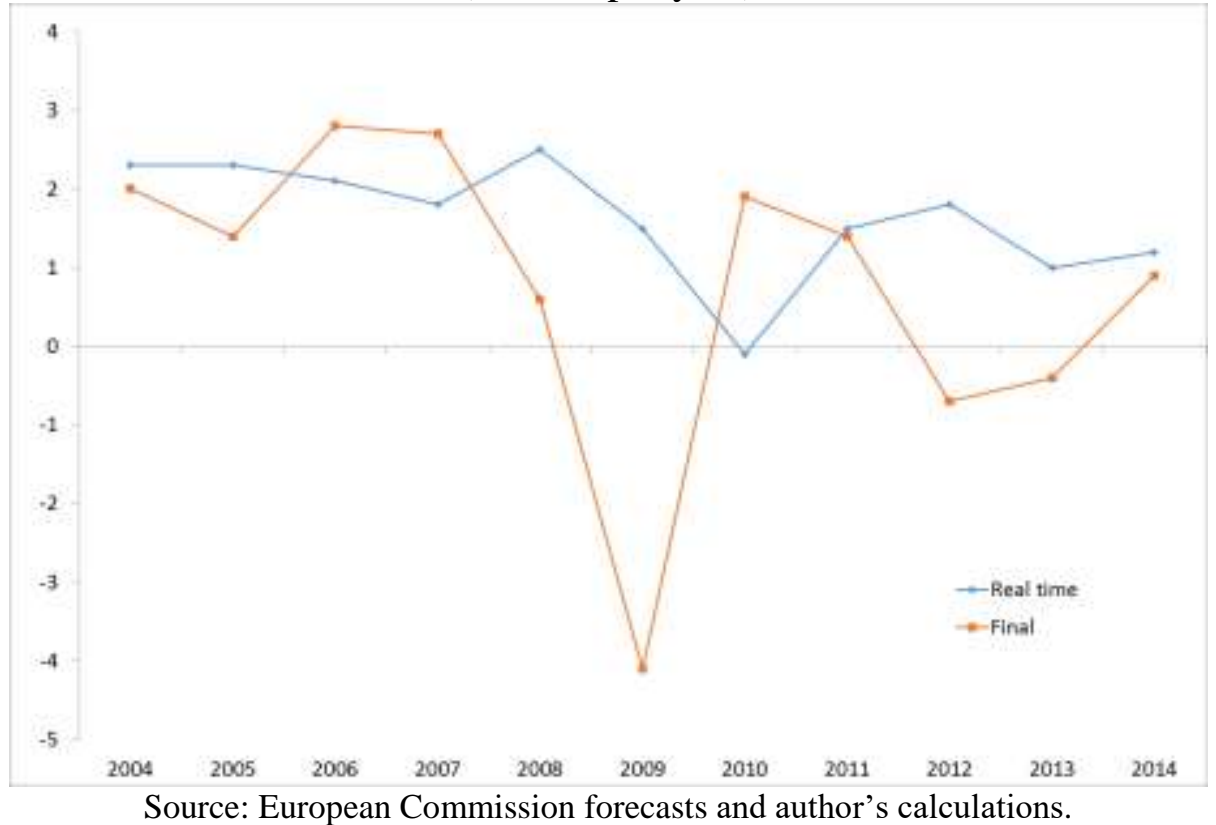

Not surprisingly, GDP forecast inaccuracy translates into large errors when forecasting the output gap (Figure 5). Over 2004-2014, the root-mean square error is 0.5 percent of potential GDP. This means that the fiscal stance decided in year $t-1$, based on the forecasted output gap for year $t$, will likely be irrelevant since the output gap on average differs by 0.5 percentage points from what was initially expected. The correlation between the real time and the final figure of the output gap is only $44 \%$ over this period. In the recent period, it seems that the output gap forecasted in year $t-1$ for year $t$ follows closely the output gap observed in $t-1$.

Figure 5: Real time and final output gaps in the euro area

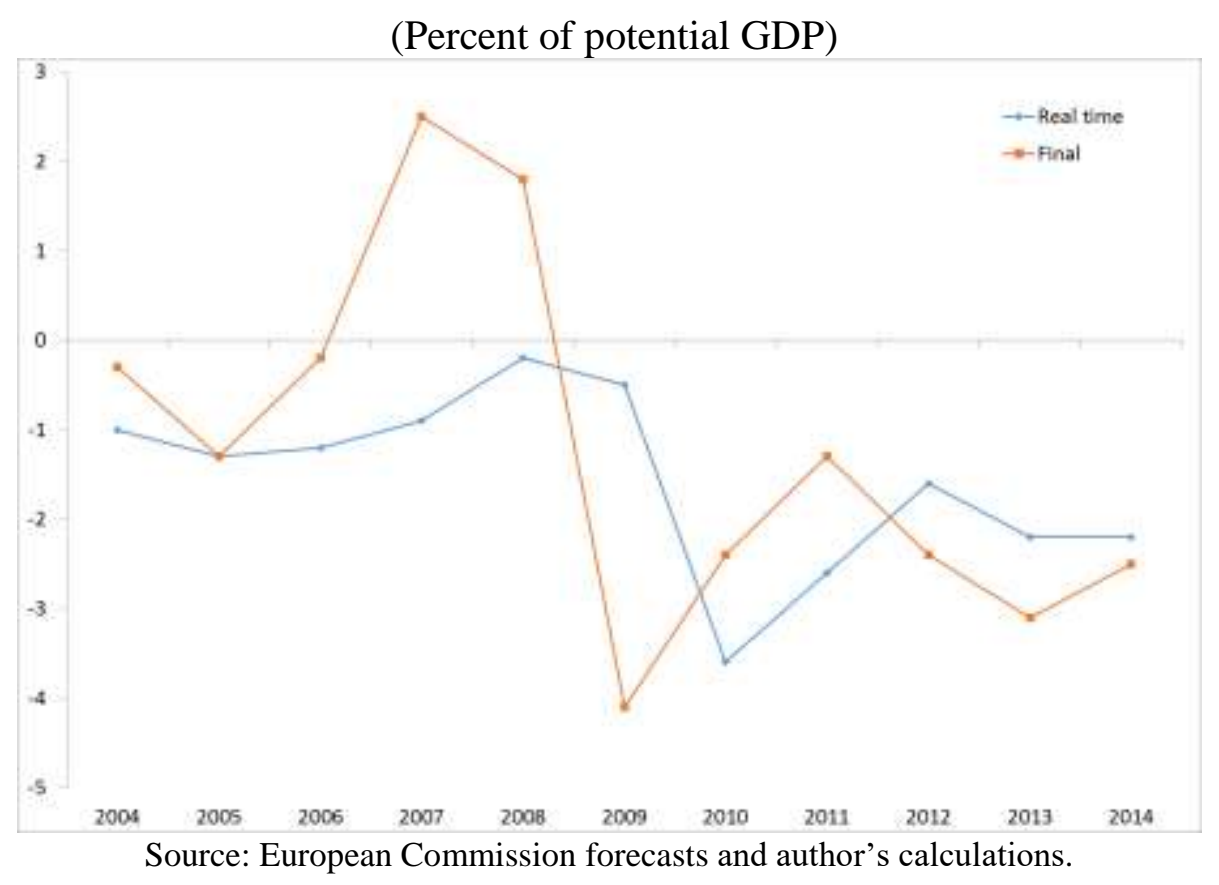

Several authors have pointed out that fiscal plans may be counter-cyclical while fiscal outcomes turn out to be pro-cyclical (see Cimadomo, 2012). Figure 6 illustrate this feature for the euro area over 2004-2014. The left hand-side panel shows the evolution of the output gap and of the structural balance as planned in the spring prior to each calendar year ("real time"). The real time structural 
balance falls sharply with the real time output gap in 2010 and stays stable in 2011 when the output gap, although recovering, is still very negative. In 2012, the structural balance adjusts sharply, consistent with improved output gap. ${ }^{16}$ Only in 2013 is the planned, real time adjustment inconsistent with the deterioration of the real time output gap.

Figure 6: Structural balance and the output gap in the euro area: real time vs final data

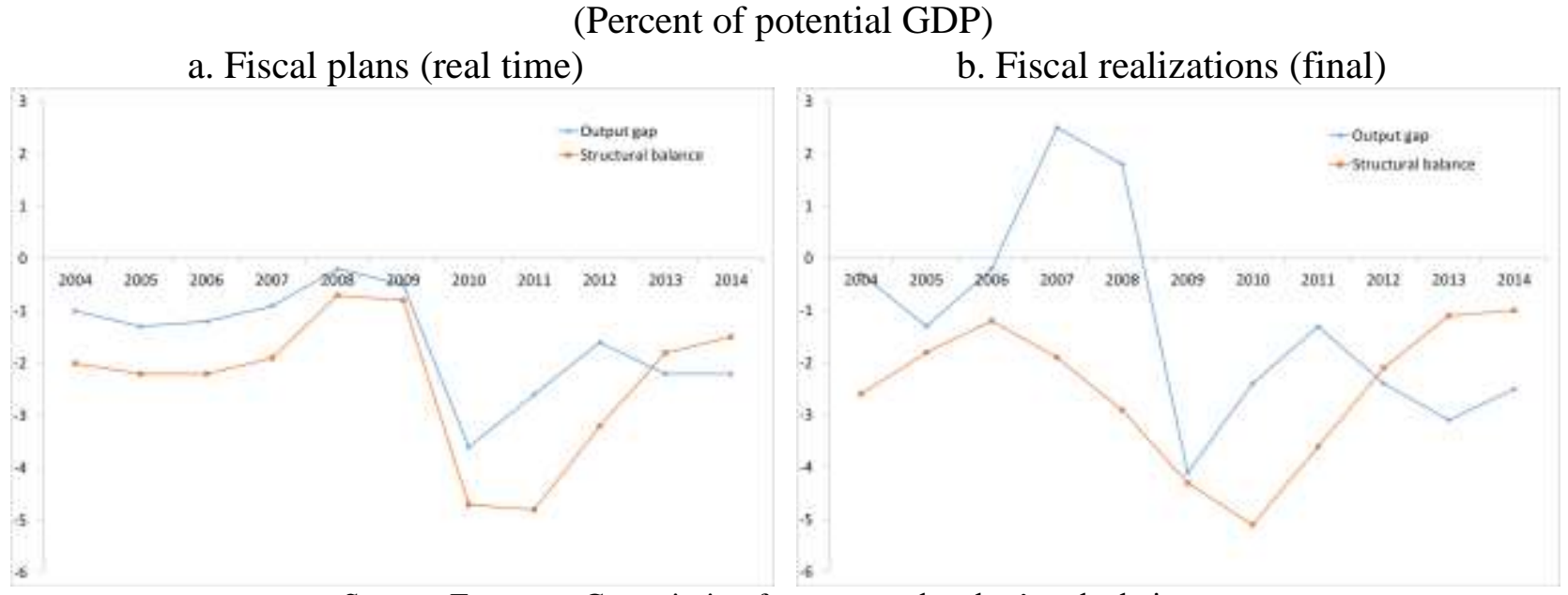

Source: European Commission forecasts and author's calculations.

The ex post picture (i.e. "final", cf. right hand-side panel) appears somewhat different. First, the output gap is revised strongly upwards for 2007-2008 and downwards for 2009. In 2009, the fiscal stance appears counter-cyclical since the structural balance deteriorates by 1.4 percent of potential GDP. In 2010, the output gap recovers, but the structural balance continues to deteriorate. In 2011, the fiscal adjustment is in line with the output gap recovering. In 2012 and 2013, however, fiscal adjustment continues while the output gap deteriorates, which amounts to a pro-cyclical policy. In 2014, finally, fiscal adjustment is more limited while the output gap slightly recovers. ${ }^{17}$

Figure 6 shows that the fiscal stance of the euro area was unable to adapt itself to the unexpected "second dip" of the output gap in 2012 and 2013, in sharp contrast with its reaction to the "first dip" (2009). As shown by Bénassy-Quéré, Ragot and Wolff (2015), adjustment programmes in the crisis countries only contributed 0.6 percent of euro area's GDP in 2012 and 0.2 percent in 2013. Germany alone contributed 0.35 percent of euro area's GDP in 2012 and 0.1 percent in 2013. The response to the second dip could have come from loser monetary policy rather than more expansionary fiscal policy. ECB's interest rates were cut by 0.25 percentage point in 2012 and $0.5 \mathrm{pp}$ in 2013. However, the ECB's balance sheet started to decline in the fall of 2012 and continued to shrink over 2013, as a result of early repayments of very long term refinancing operations carried out in 2011; consistently, the euro appreciated over this period (see Bénassy-Quéré et al., 2014). The fact is that the combination of monetary and fiscal policy was probably not appropriate at this juncture.

\subsection{Alternative measures of the supply-demand imbalance}

The question then is whether the fiscal plans could be designed based on a more reliable measure of the cycle than the output gap. Because fiscal policy is aimed at smoothing the level of demand around

\footnotetext{
${ }^{16}$ These adjustment figures are given compared to the previous real time figure; they are much smaller compared with the previous observed figure.

${ }_{17}$ The same exercise is reproduced for the financial balance (or net lending) in Appendix 1. It shows similar contrast between fiscal "intentions" and "realizations".
} 
the level of supply, we are looking for an indicator of the supply-demand imbalance. There are two candidates: inflation, and the current account. ${ }^{18}$

Figure 7 compares the EC's real-time estimations of the euro area consumer-price inflation (Spring of $t$-1) with the final figure (Spring of $t+2$ ), from 2004 to 2014. The fit between the two lines appears even worse than for the output gap: while real-time inflation is relatively stable "close but below 2\%", the final figure varies from 0.3 to $3.3 \%$. The correlation between real time and final inflation is close to zero over this period. Hence, although inflation should naturally react to the ex-ante gap between demand and supply, in practice this variable is not a reliable indicator for fiscal policy. ${ }^{19}$

Figure 7: Real time and final consumer price inflation in the euro area

(Percent per year)

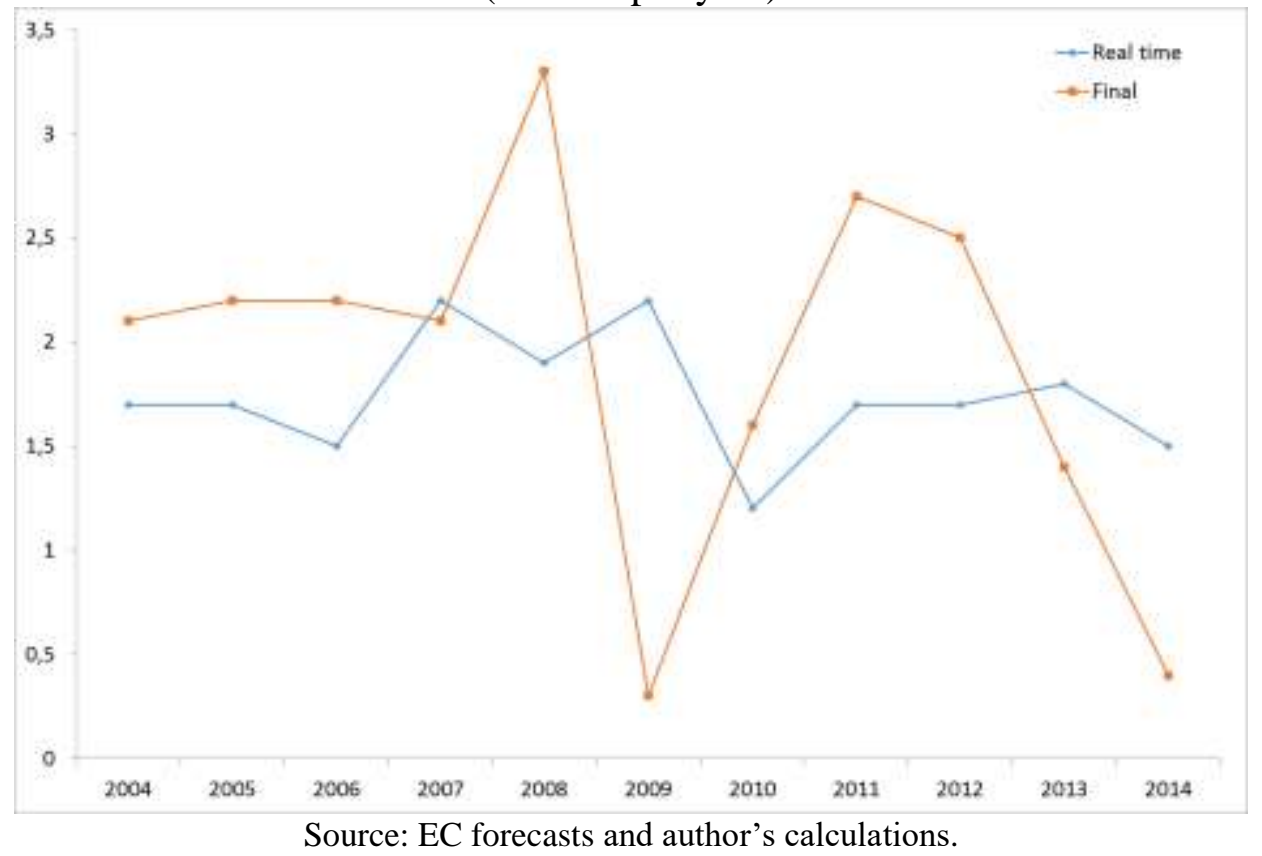

Figure 8 displays the same comparison for the current account of the euro area between 2004 and 2014. Starting in 2010, there is a systematic under-estimation of the current account. Still, the expected evolution of the current account is correct during most of the period, and the correlation between the real time and final series is $64 \%$.

\footnotetext{
18 The current account is equal to the excess of saving over investment at the level of the nation. Since saving is the difference between income and consumption, the current account stands out as an aggregate measure of excess supply over demand. In case of a current account surplus, the lack of domestic demand is compensated by foreign demand; in case of a deficit, the excess demand is satisfied through net imports.

${ }^{19}$ Core inflation, (i.e. HICP inflation excluding energy and unprocessed food) may be more closely related to the output gap, and easier to predict. However, the European commission does not publish its forecasts of core inflation.
} 
Figure 8: Real time and final current account in the euro area

(Percent of GDP)

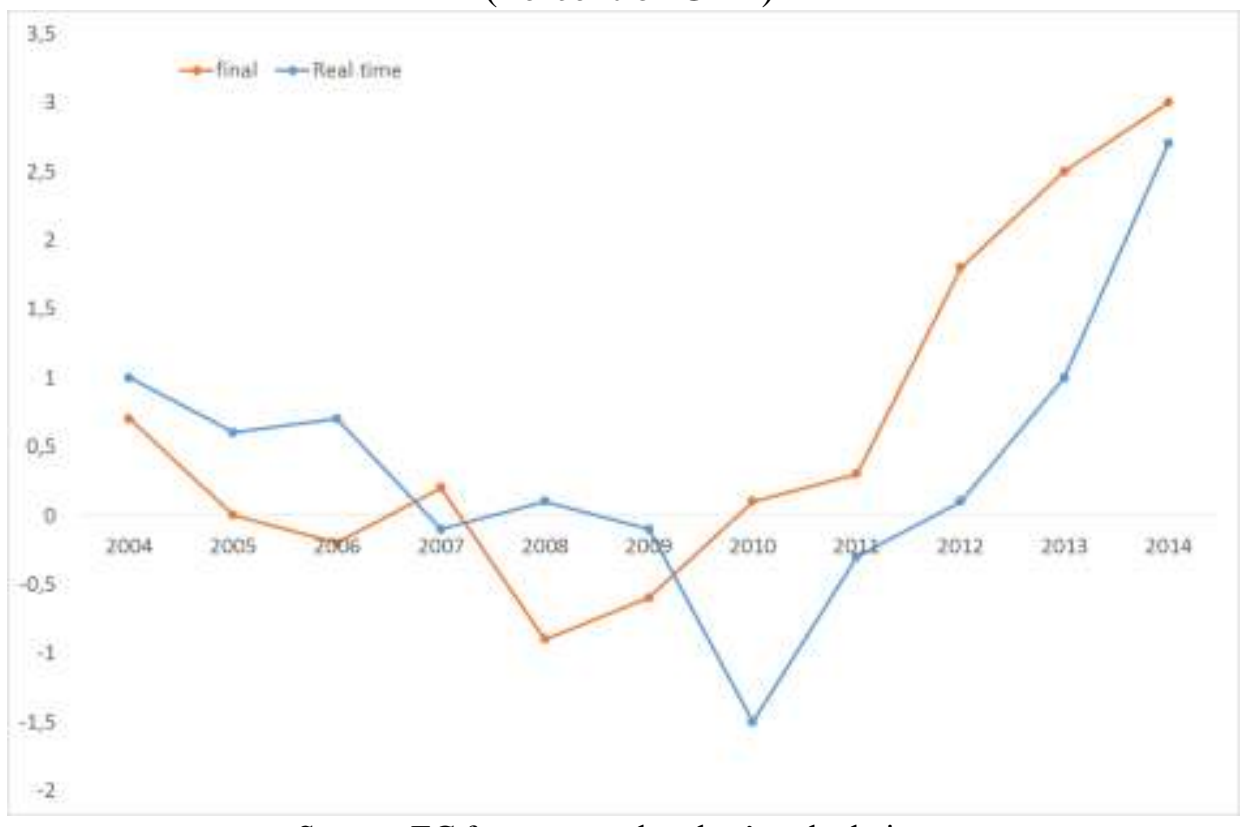

Source: EC forecasts and author's calculations.

We conclude that the forecasted current account should be used alongside the forecasted output gap when deciding on the fiscal stance. Unlike the output gap, the current account can be observed in national accounts; hence, persistent errors are less likely for the current account than for the output gap.

\subsection{The fiscal stance and the current account}

We now assess the "real time" and "final" fiscal stances in comparison no longer with the output gap but now with the current account. Figure 9 shows a much less contrasted picture between real time and final figures than in the case of the output gap. In particular, the pro-cyclical policy surprise shown in Figure 6 for 2012 and 2013 no longer appears in Figure 9: both in real time and with final data, fiscal policy contracts at a time when the gap between supply and demand (the current account) increases. Had the predicted rise in the current account be taken seriously in 2011 as an indicator of excess supply, the fiscal stance could have been calibrated in a less pro-cyclical way. ${ }^{20}$

${ }^{20}$ The same exercise is reproduced in Appendix 1 for the financial balance, with similar conclusion. 
Figure 9: Structural balance and the current account in the euro area (Percent of potential GDP)

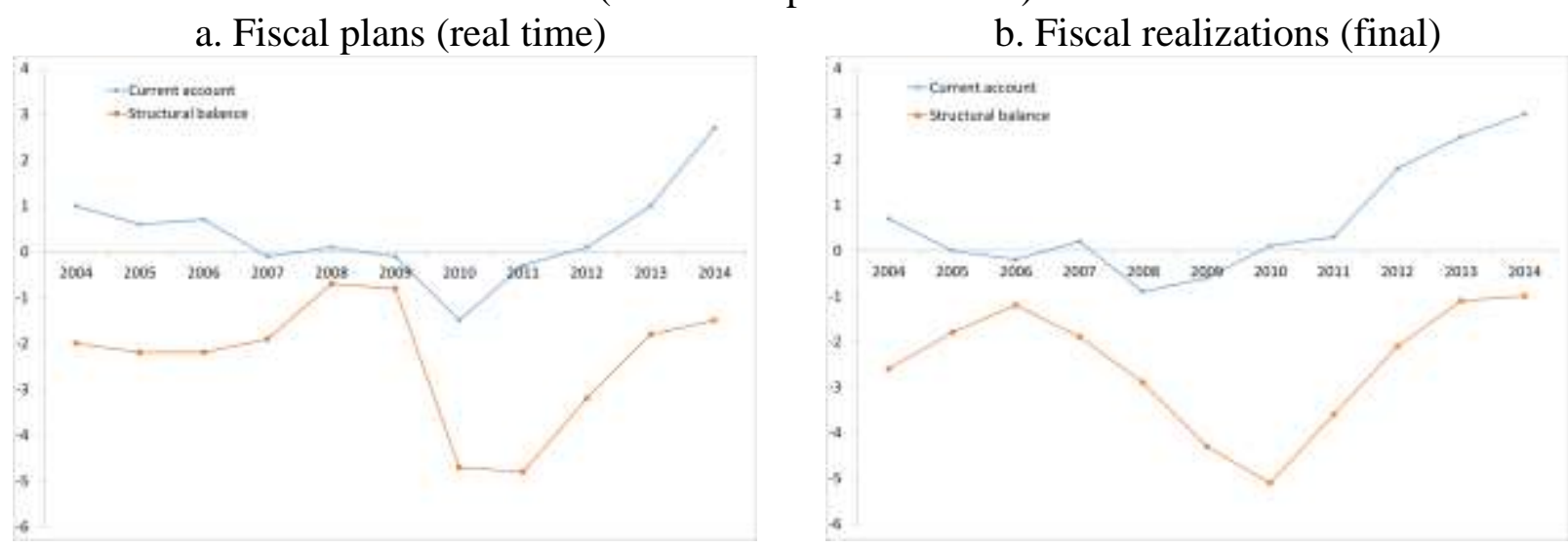

Source: EC forecasts and author's calculations.

It can be argued that the current account is endogenous to the fiscal stance: fiscal contraction weighs on demand, hence it improves the current account. This is true, but it the output gap too is endogenous to fiscal policy. It can be noted in Figure 9 that, in 2012 and 2013, the fiscal stance is pro-cyclical even with respect to the observed current account in 2011 and 2012, respectively. Although there is clearly a link between the output gap and the current account, the latter variable appears more reliable than the former to set a counter-cyclical fiscal stance one year in advance.

\subsection{Objecting to the current account}

It may be argued that the rising current account of the euro area over the 2008-2014 period is the result of higher competitiveness rather than excess supply. However, the global market share of the euro area (excluding intra-zone flows) fell by 0.6 pp from 2008 to 2014 (Figure 10). Symmetrically, the experience of Spain prior to the crisis shows that a country may record stable market shares with a deepening current-account deficit.

Figure 10: World market share and the current account, euro area

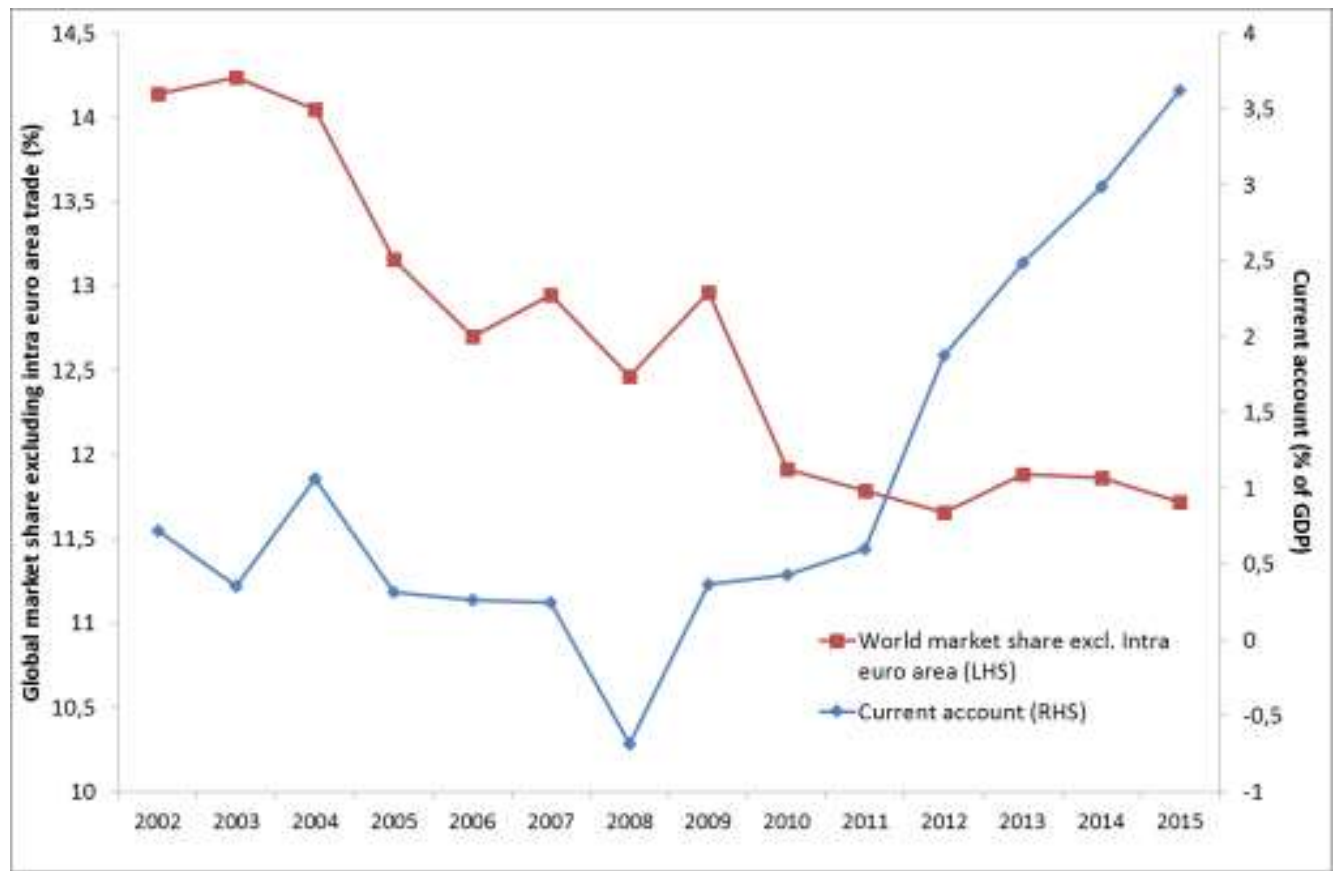

Source: Ameco.

It may also be argued that the rising current account is the result of an ageing population, which tends to save more and invest less domestically. However ageing is a smooth process, whereas the rise in the current account is a sudden event starting in 2012 (Figure 11). 
Figure 11: Population ageing and the current account, euro area

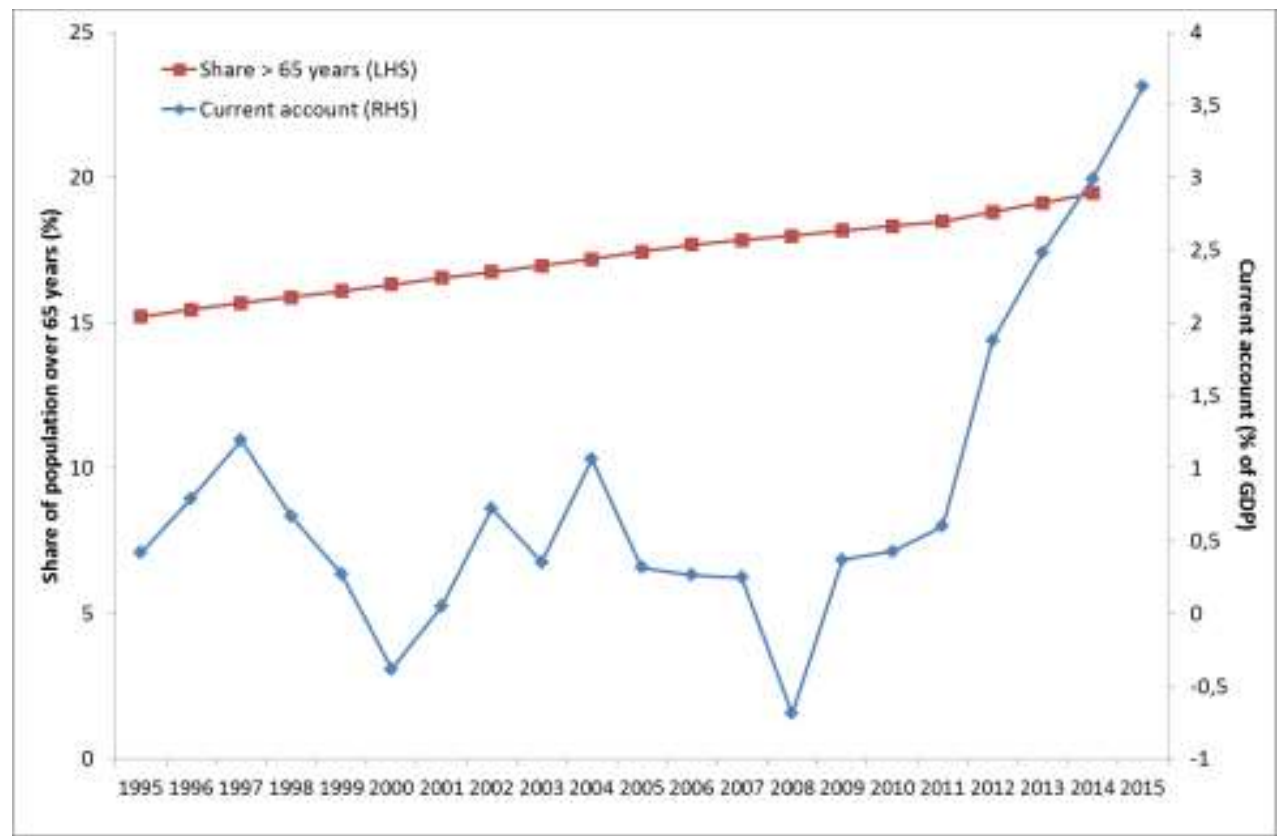

Source: Ameco.

Finally, the rise in the euro area current account may be due to the sharp fall in the prices of oil and other commodities in the recent period. To the extent that these price variations are not expected to be long-lasting, the windfall would be saved, and the current account would rise. Figure 12 evidences that from 2013 to 2015, euro area's terms of trade increased in parallel to the current account. However euro area's terms of trade fell sharply from 2009 to 2012, while the current account was already rising.

Figure 12: Terms of trade and the current account, euro area*

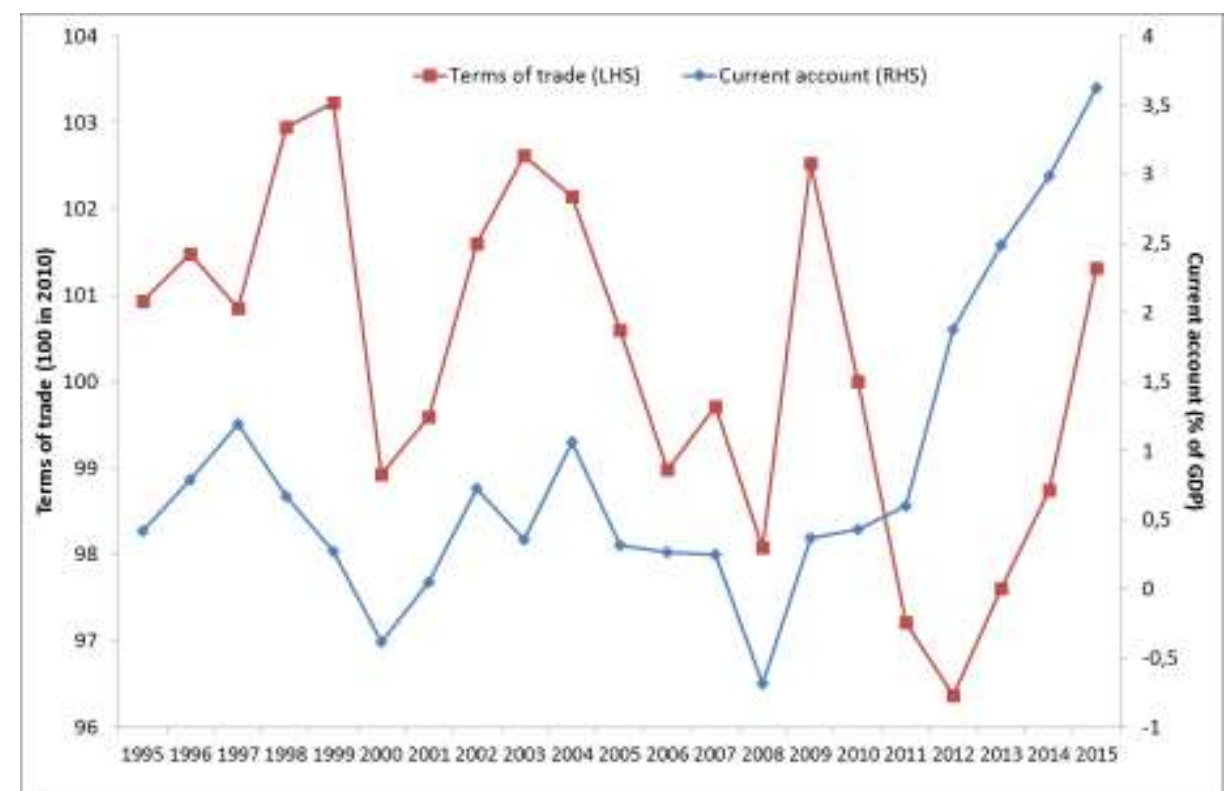

* Euro area terms of trade are a weighted average of terms of trade of the four largest euro area economies (Germany, France, Italy and Spain).

Source: Ameco and author's calculations. 


\subsection{Designing a euro area fiscal stance}

The practical implication of the above analysis is that the discussion on aggregate fiscal stabilization should rely on the expected current account as a complement to the expected output gap. Figure 13 provides a case study for years 2008 to 2014. The fiscal stance is calculated as the yearly variation of the structural balance for the euro area. The "final" fiscal stance is the difference between two final values, whereas the "real-time" fiscal stance is the difference between the budget plan made in Spring $t-1$ for year $t$ and the revised figure in Spring $t-1$ for year $t-1$. Hence, it is the difference between the one year ahead forecast and the observed situation by the time the forecast is made.

The fiscal stance of the euro area is assessed according to two measures of the supply-demand imbalance: the output gap (horizontal axis), and the current account (vertical axis). A counter-cyclical fiscal policy is expected to locate in the North-West and South-East quadrants: the fiscal stance needs to be expansionary when the output gap is negative and the current account is in surplus; it needs to be contractionary in the opposite situation. According to this taxonomy, a negative output gap accompanied with current account deficit, or a positive output gap accompanied with a current account surplus, would need further analysis since the two variables point in different directions.

Contrasting with the output gap, the current account needs not be balanced on average. An ageing economy like the euro area would expected to run a current account surplus on average, whose amount would need to be estimated (see e.g. Cheung et al. 2013). Hence the term "current account surplus" may in fact refer to a surplus higher than, say, 2 percent of GDP. It remains that the fiscal stance would usefully be assessed against the current account as a complement to the output gap.

Figure 13: Real time and final fiscal stance in a two-dimension space, 2008-2014

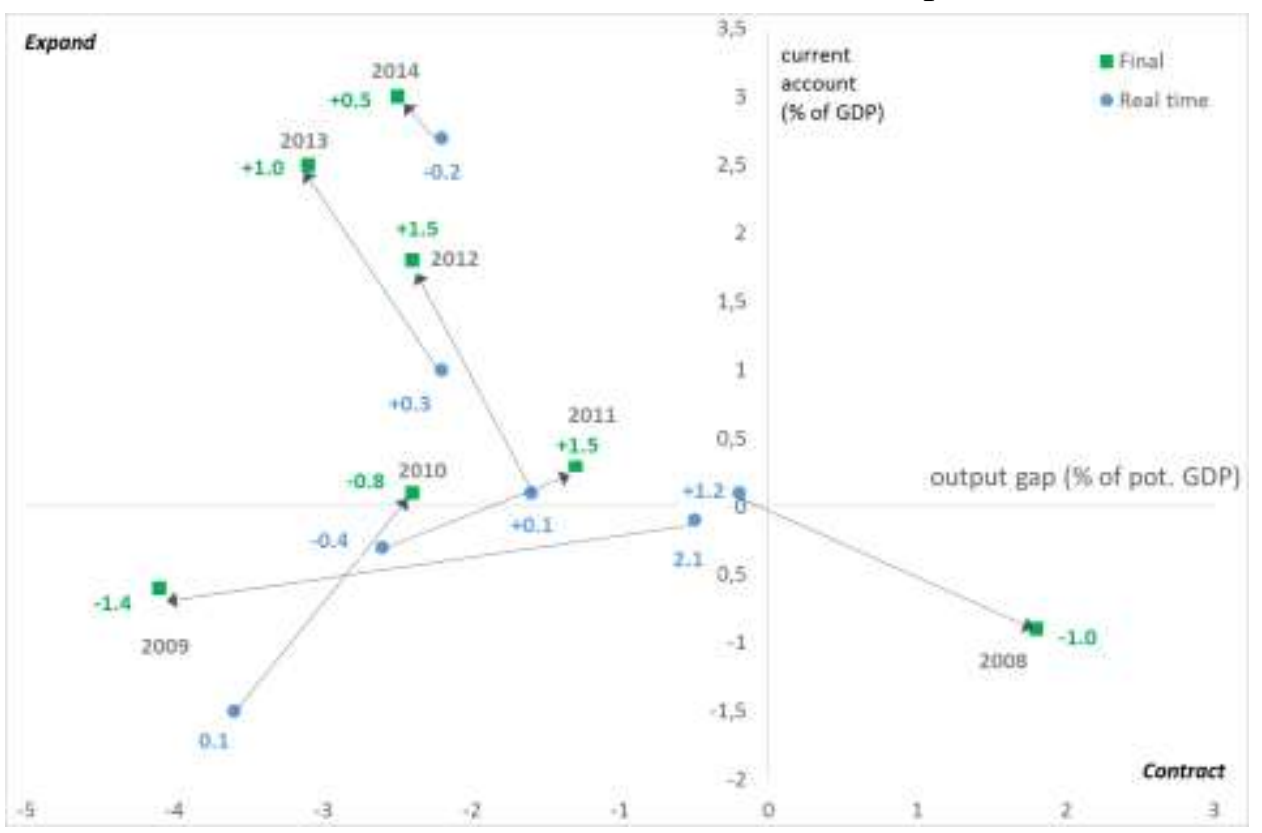

Blue circles correspond to real time values, whereas green squares are final values. The blue and green figures are the real-time and final fiscal stance, respectively, corresponding to each year indicated in grey.

Reading: in 2014, the real-time fiscal stance was a $0.2 \mathrm{pp}$ easing, for a $-2.2 \%$ output gap and a +2.7 pp current account surplus; the same year, the final fiscal stance was a $0.5 \mathrm{pp}$ contraction, for a $-2.5 \%$ output gap and +3 pp current account surplus.

Source: EC forecasts and author's calculations.

Figure 13 shows that moving to the North-West (i.e. with more negative output gap and more positive current account) does not involve a more expansionary fiscal stance over 2008. Over 2012-2014, the real time current account increases while the real time output gap stays stable at around $-2 \%$. Yet, only in 2014 is the real time fiscal stance expansionary. Over the same period, final figures systematically show a more negative output gap and a more positive current account than initially thought; yet the fiscal adjustment is more pronounced than initially planned. 
In Annex 2 we incorporate the above analysis in the design of an "optimal" fiscal stance, i.e. a fiscal stance that would make the optimal strike between sustainability (objective 1) and stabilization (objective 2). Such "optimal" policy can be written as a reaction function of either the output gap or of a "current account gap" which is the difference between the observed or projected current account and its "underlying" value that would be observed with no output gap (see, e.g., Salto and Turini, 2010; Haltmaier, 2014; European Commission, 2015a). The two reaction functions are equivalent in theory. However, given the superiority of current account forecasts with respect to GDP forecasts (see supra), it would be appropriate to cross-check the standard, output gap version of the fiscal reaction function with the current account version of it, while keeping in mind that neither of them should be applied in a mechanical way.

\subsection{Country distribution of a euro area fiscal stance}

As argued supra, fiscal coordination does not necessarily involve all governments moving in the same direction. In order to "distribute" the fiscal stance within the euro area, the output gap and current account of each country need to be taken into account, on the top of each country's "fiscal space" that results from the debt ratio. Figure 14 plots the contribution of each of the four largest euro area countries (accounting together for 78 percent of euro area's GDP) to the aggregate output gap and to the aggregate current account, from 1991 to $2015 .^{21}$ The two panels provide contrasted assessments on the distribution of imbalances. For instance, Germany has negligible output gap but positive and growing current account in the recent years, while France appears in excess supply in terms of the output gap but excess demand in terms of the current account. In Italy and Spain, the two measures of imbalances seem to coincide, with a negative output gap and a positive and growing current account.

As a first pass, the reaction function approach sketched out in Annex 2 could be used to calibrate a consistent distribution of the euro area fiscal stance across the member countries. Each variable would then need to be expressed as a contribution to the euro area aggregates, like in Figure 14, and the specific structural requirements related to the SGP would have to be incorporated. Although such approach could not be applied in a mechanical way, it could provide a reasonable starting point for the country by country budgetary recommendations and assessments.

\footnotetext{
${ }^{21}$ The graph relies on "final" data (except year 2015 for which the final data are not available). The different countries are weighted with their share in euro area's GDP in 2015.
} 
Figure 14: Contributions to supply-demand imbalances in the euro area

Contributions in the output gap

(\% of euro area's potential GDP)

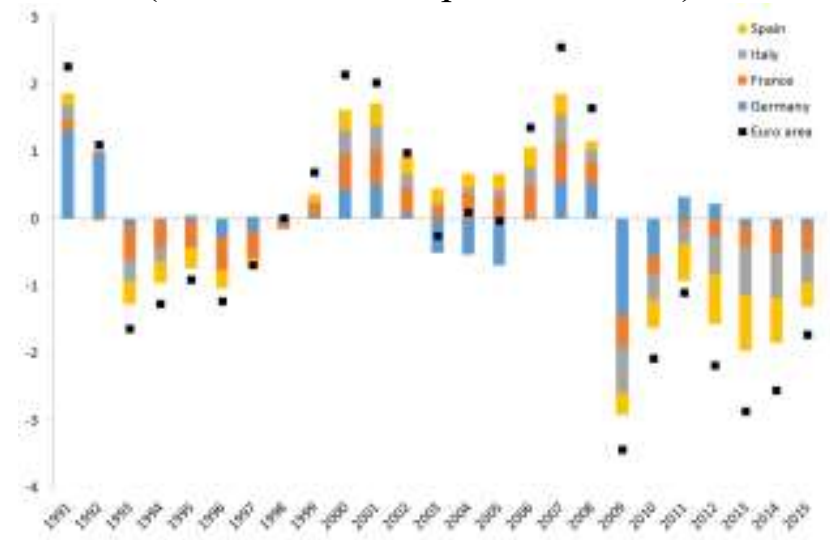

Contributions in the current account (\% of euro area's GDP)

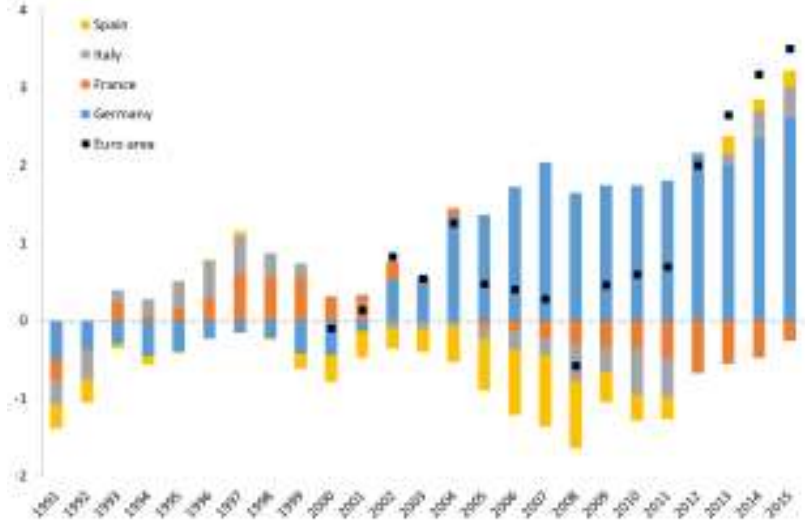

Source: Ameco and author's calculations.

\section{GOVERNING THE AGGREGATE FISCAL STANCE}

\subsection{The existing setup}

Under the current setup, the aggregate fiscal stance for years $t+1$ and $t+2$ is assessed by the EC in November $t$, through the "Overall assessment of the draft budgetary plans" and the "Recommendation to the euro area", "against the twin objectives of long-term sustainability of public finances and shortterm macroeconomic stabilisation" (European Commission, 2015b, p. 1). These assessments are based on national Stability programmes (transmitted in April $t$ ) and Draft budgetary plans (transmitted in October $t$ ). The euro area as such is not required to produce any "Aggregate stability programme" or "Aggregate budgetary plan". Hence the exercise is essentially bottom-up: the EC sums up national budgets and assesses whether the aggregate makes sense given the dual objective of sustainability and stabilization. Furthermore, the assessment of national draft budgetary plans (also issued in November $t$ ) hardly mentions the term "Euro area". As for country-specific recommendations issued in May $t+1$, in theory they may incorporate the November $t$ assessment for the euro area as a whole. In practice the link is very loose. For instance, individual fiscal stances are not expressed in percent of aggregate euro area's GDP (only in terms of individual countries' GDP).

Within existing institutions, the "Euro area" cannot draft an aggregate stability programme and an aggregate draft budgetary plan, since there is no Euro area ministry of Finance (and no euro area budget). Should there be a ministry of Finance, the question would then be whether it would have any command on national budgets. Still, within existing institutions, the connection between euro area and national assessments could be improved by issuing a note on the desirable fiscal stance for $t+1$ immediately after the Spring $\boldsymbol{t}$ forecasts are published. ${ }^{22}$ Such assessment could rely at least partially on the expertise of the EFB. In their budgetary plans, the member states would then need to explicitly explain how they contribute to the euro area fiscal stance, given their own fiscal space. The "Overall assessment of draft budgetary plans" in November $t$ could then explicitly compare the Spring $t$ top-down advise and the November $t$ bottom-up plan.

\subsection{The subsidiarity principle}

\footnotetext{
${ }^{22}$ See Bénassy-Quéré and Ragot (2015).
} 
The subsidiarity principle is defined in Article 5.3 of the Treaty on the Functioning of the European Union:

"Under the principle of subsidiarity, in areas which do not fall within its exclusive competence, the Union shall act only if and in so far as the objectives of the proposed action cannot be sufficiently achieved by the Member States, either at central level or at regional and local level, but can rather, by reason of the scale or effects of the proposed action, be better achieved at Union level." (Art. 5.3)

The question then is whether the "stability" of the euro area can be achieved by Member states in a decentralized way, or whether some collective action is needed to reach the objective of stability.

Stability here has two different meanings: "financial stability", and "macroeconomic stability". Although they sometimes overlap, these two meanings refer to two different concepts when fiscal policy is at stake. Financial stability is related to fiscal sustainability, with the idea that fiscal unsustainability may destabilize the financial sector in the euro area. As for macroeconomic stability, it is related to the need to keep GDP close to its potential level in order to avoid both cyclical unemployment and price instability. ${ }^{23}$

Fiscal rules were initially introduced with the objective of limiting the risk of financial instability (itself being related to fiscal unsustainability). Hence, the objective of "financial stability" has always been considered unachievable through pure decentralization of fiscal policy. The question now is whether the objective of macroeconomic stability can be achieved based on decentralized policies (with the constraint of the SGP), or whether some collective action is needed.

Following Bénassy-Quéré, Ragot and Wolff (2015), we would argue that, in normal times, the usual "bottom-up" approach of fiscal policy is appropriate, given the limited spillovers reviewed in Section 2. In exceptional times, however, fiscal spillovers are much more powerful, which justifies switching to a "top-down" approach.

\subsection{The European fiscal board}

Consistent with the above analysis, we think that the newly created EFB would need to advise the Commission and stir a debate on the whether the euro area is in "exceptional times" or not. Following the EC's Spring $t$ forecasts, the EFB could issue an advice to the EC on (i) whether the euro area is expected to be in "normal" or "exceptional" times in $t+1$, (ii) the desirable aggregate fiscal stance for year $t+1$, and (iii) if the euro area is considered to be in "exceptional" times, and in cooperation with national fiscal Councils, a proposition of how the aggregate fiscal stance could be distributed across the Member states.

"Exceptional times" would appear either in case of a large aggregate shock (like in 2009) or when there is a risk that the ECB is unable to stabilize the euro area economy alone. This may happen at the zero lower bound (2012-2013), or conversely when financial risks are accumulating in the economy while inflation is at its target level and macro-prudential instruments are found insufficient (before 2008). Indeed, as evidenced in Section 2, it is in good times that national fiscal policies tend most to be pro-cyclical. ${ }^{24}$

\footnotetext{
${ }^{23}$ Additionally, IMF (2015a) finds a significant impact of GDP volatility on long-term growth.

${ }^{24}$ In order to correct for pro-cyclical policies in good times, switching from a deficit rule to an expenditure rule could be useful, see Cordes et al. (2015). With the "six pack", an expenditure rule was added to the deficit rules, but the binding constraint has remained the deficit.
} 
More specifically, the EFB could advise the Commission on triggering the escape clause of the SGP, using the flexibilities of the SGP ${ }^{25}$ or, on the upside, reinforcing the consolidation requirements relative to the SGP, possibly with some incentive given to national governments.

Without a Treaty change, the legitimacy of a "top-down" approach of fiscal policy will mainly rely on "output legitimacy": it will need to be built based on its efficacy. However, the EFB could also have an impact through raising the level of awareness within the European and national Parliaments. The President of the EFB would need to be heard by the EP at least once a year. Hearings in large Member states, which make the bulk of the fiscal stance, would also be necessary.

Since national governments and parliaments will remain responsible for national fiscal policies, fiscal coordination will remain fragile. It may be more acceptable when occurring only in "exceptional times". However, there is no guarantee that national budgets will go in a direction consistent with the top-down approach, especially when the macroeconomic situation differs largely across Member states. Therefore, the coordination of national fiscal policies should be complemented by the development of a "fiscal capacity" for the euro area, which at some point may replace the coordination scheme, just like the EMU replaced the ERM in 1999.

\subsection{Reducing fiscal noise}

There are two reasons for focusing SGP rules on structural fiscal adjustment. The first one is to remove the cycle from both the numerator and from the denominator of the deficit ratio. The second reason is that, since governments can hardly control the denominator, using a relatively stable denominator helps the budgetary process.

In practice, however, potential growth may be revised not only from one year to the other (see Figure 1 in Section 1), but also within the same year, along the three successive vintages of the EC forecasts (winter, spring and autumn). Revising potential growth downwards automatically involves a requirement of additional fiscal consolidation. Given that potential growth is both highly debatable and a long-term concept, the assumptions concerning it should be set only once a year. This would help governments concentrating on achieving the most adequate real-time balance between long-term sustainability and short-term macroeconomic stabilisation.

If potential growth has been over-estimated during a year or more, then the country will need to catch up later on, and the Commission should allow the appropriate delay to do so. Presently, revisions of potential growth are taken into account when assessing structural adjustment under the Excessive Deficit procedure (EDP). The assessment is also complemented with a "bottom-up" approach of structural efforts, which adds up the impact of individual revenue measures and estimates the gap between expenditure measures and a "no policy change" scenario. So normally a country cannot be sanctioned due to a revision of potential growth. However, these revisions create useless noise in national fiscal debates, reduce the ownership of the rules, and make the application of the rules so complicated that they no longer appear to be rules. ${ }^{26}$

\section{CONCLUSIONS}

The design and implementation of a Euro-area fiscal stance is especially difficult in the absence of a Euro-area budget. The only possibility is to coordinate national fiscal policies in order to mimic what a federal budget could achieve. We have argued in this report that such "top-down" approach should apply only in "exceptional" times, when fiscal spillovers are high and the Euro area at risk. In "normal" times, the usual "bottom-up" approach remains appropriate.

\footnotetext{
${ }^{25}$ Aviat et al. (2016) show that the flexibilities of the SGP where far from fully used in 2012, while in 2015 they were over-used.

${ }^{26}$ See Eyraud and Wu (2015), or European Parliament (2015).
} 
Because of the twin objective of fiscal sustainability and fiscal stabilization, and despite necessary simplification efforts, fiscal rules will remain relatively complicated and will require judgment. In order not to transform judgment into pure discretion, strong fiscal boards will be key, both at national level and at euro-area level. Making the distinction between normal and exceptional times will mean that national fiscal councils remaining fully in charge most of the time, which will preserve national ownership. In exceptional times, a coordination between the EFB and national fiscal councils should be organized so as to deliver consistent messages.

Fiscal boards and policy coordination will however remain in the domain of "soft power": their impact on budgetary plans will rely on persuasion. Although a broad-based debate with national as well as the European Parliament will help raising awareness on common problems and solutions, the building up of a genuine fiscal capacity for the euro area will probably be necessary at some point. 


\section{REFERENCES}

Aurbach, A.J., and Y. Gorodnichenko (2013), "Output spillovers from fiscal policy", American Economic Review: Papers and Proceedings, 10 (3), pp. 141-146.

Aviat, A., Diot, S., El Kasmi, S., and N. Jégou (2016), "Toward a better management of the fiscal stance in the euro area?", Trésor-Economics No. 163, March.

Beetma, R., Giuliodori, M., and F. Klaassen (2006), "Trade spill-overs of fiscal policy in the European Union: a panel analysis", Economic Policy, 21 (48), pp. 639-687.

Beetsma, R., and X. Debrun (2016), "Fiscal Councils: Rationale and Effectiveness", IMF working paper WP/16/86.

Bénassy-Quéré, A., Gourinchas, P.O., Martin, P. and G. Plantin (2014), "The euro in the 'currency war'”, French Council of Economic analysis, Note No. 11, January.

Bénassy-Quéré, A., and X. Ragot (2015), "A policy mix for the euro area", French Council of Economic Analysis, Note No. 21, March.

Bénassy-Quéré, A., Ragot, X., and G. Wolff (2016), "Which fiscal union for the euro area?", Note of the Conseil d'Analyse Economique, 29, February.

Blanchard, O., Erceg, C.J., and J. Lindé (2015), "Jump starting the euro area recovery: would a rise in core fiscal spending help the periphery?", NBER working paper No. 21426.

Calmfors, L., and S. Wren Lewis (2011), "What should fiscal councils do?", CESIfo working paper No. 3392.

Carnot, N., and F. de Castro (2015), "The discretionary fiscal effort: an assessment of fiscal policy and its output effect", European Economy, Economic Papers 543, February.

Cheung, C., Furceri, D., and E. Rusticelli (2013), "Structural and cyclical factors behind current account balances", Review of International Economics, 21 (5), pp. 923-944.

Cimadomo, J. (2012), "Fiscal policy in real time", Scandinavian Journal of Economics, 114 (2), pp. 440-465.

Claeys, G., Leandro, A., and A. Mandra (2015), European Central Bank Quantitative Easing: The Detailed Manual", Bruegel Policy Contribution, 2015/02, March.

Cordes, T., Kinda, T., Muthoora, P., and A. Weer (2015), "Expenditure rules: effective tools for sound fiscal policy?", IMF working paper, WP/15/29.

Cwik, T., and V. Wieland (2010), "Keynesian government spending multipliers and spillovers in the euro area", ECB working paper No. 267, November.

Debrun, X., and R. Kapoor (2011), "Fiscal policy and macroeconomic stability: automatic stabilizers work, always and everywhere", IMF working paper WP/10/111.

De Grauwe, P. and Ji, Y. (2013), "Self-fulfilling crises in the Eurozone: an empirical test", Journal of International Money and Finance, 34. 15-36.

Eichengreen B. and Ch. Wyplosz (1998): «The Stability Pact: More than a Minor Nuisance? », Economic Policy, 13 (26), pp. 65-104.

European Commission (2015a), Spring Forecasts, Box 1.3.

European Commission (2015b), "2016 draft budgetary plans: overall assessment", Communication, $\operatorname{COM}(2015)$ 800, final, 16 November.

European Parliament (2015), "Report on the review of the economic governance framework: stocktaking and challenges", Committee on Economic and Monetary Affairs (Rapporteur: Pervenche Bérès), 17 June.

Eyraud, L., and T. Wu (2015), "Playing by the Rules: Reforming Fiscal Governance in Europe", IMF working paper WP/15/67.

Fioramanti, M., González Cabanillas, L., Roelstraete, B., and S.A. Ferrandis Vallterra (2016), "European Commission's Forecasts Accuracy Revisited: Statistical Properties and Possible Causes of Forecast Errors", European Commission Discussion Paper No. 27, March.

Goujard, A. (2016), "Cross-country spillovers from fiscal consolidations", Fiscal Studies, forthcoming.

Gordon, R. (2012), "Is U.S. Economic Growth Over? Faltering Innovation Confronts the Six Headwinds", NBER working paper No. 18315. 
Haltmaier, J. (2014), “Cyclically Adjusted Current Account Balances”, International Finance Discussion Papers 1126, December.

Hebous, S., and T. Zimmermann (2013), "Estimating the effects of coordinated fiscal actions in the euro area", European Economic Review, 58, pp. 110-121.

In't Veld, J. (2013), "Fiscal consolidations in the euro area periphery and core", European Economy, Economics Papers, 506, October.

International Monetary Fund (2015a), "Where are we headed? Perspectives on potential output", World Economic Outlook, Chapter 3, Spring.

International Monetary Fund (2015b), “Can fiscal policy stabilize output?”, Fiscal Monitor, Chapter 2, April.

Perotti, R. (2005), Estimating the Effects of Fiscal Policy in OECD Countries, CEPR Discussion Paper No. 4842.

Salto, M., and A. Turini (2010), "Comparing alternative methodologies for real exchange ate assessment”, Economic Papers, 427, September.

Summers, L (2014), "US Economic Prospects: Secular Stagnation, Hysteresis and the Zero Lower Bound", speech delivered to the National Association for Business Economics' Economic Policy Conference, 24 February 24.

Teulings, C., and R. Baldwin, eds. (2014), Secular Stagnation: Facts, Causes and Cures, Vox e-book, August.

Turrini, A. (2008), "Fiscal policy and the cycle in the euro area: the role of government revenue and expenditure", European Economy, Economic Papers 323, May.

Williamson, J. (1983), The Exchange Rate System, Washington, Institute for International Economics 
Figure 15: Overall budget balance and the output gap in real vs final time (Percent of GDP)
a. Fiscal plans (real time)
b. Fiscal realizations (final)

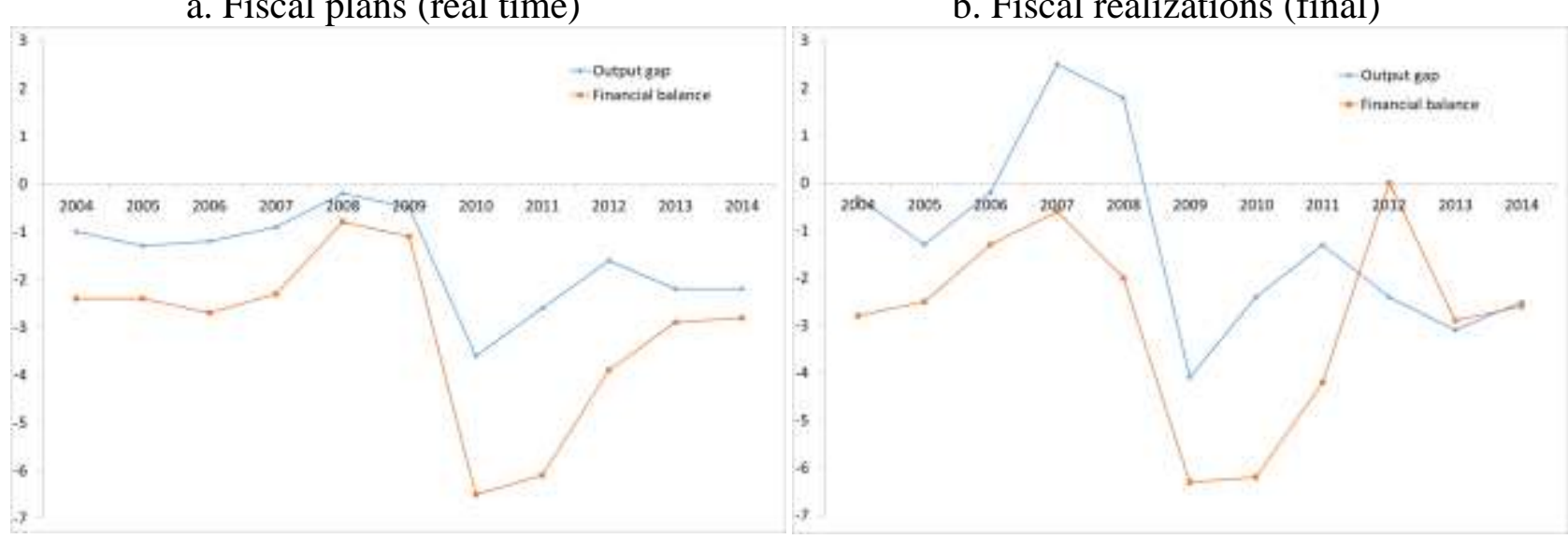

Source: EC forecasts and author's calculations.

Figure 16: Overall budget balance and the current account in real vs final time (Percent of GDP)
a. Fiscal plans (real time)
b. Fiscal realizations (final)

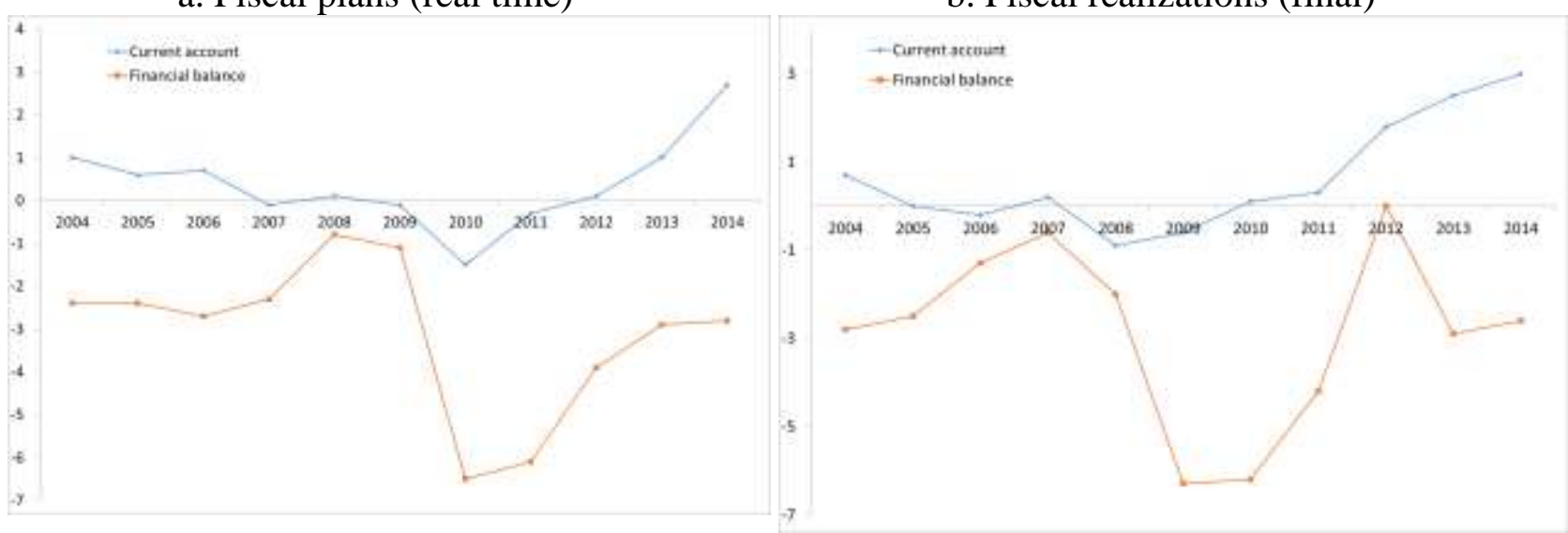

Source: EC forecasts and author's calculations. 


\section{ANNEX 2: A REACTION FUNCTION APPROACH OF THE AGGREGATE FISCAL STANCE}

Here we assume that the euro area fiscal stance aims at: (i) fiscal sustainability, which materializes in a given objective of annual structural adjustment $a$; and (ii) fiscal stabilization, i.e. an output gap $y$ equal to zero. Provided the output gap is zero, there is no reason to deviate from the structural adjustment which corresponds to the path towards meeting the medium term objectives. However, it may be appropriate to either accelerate or decelerate fiscal adjustment depending on the (expected) output gap. The dual objective can be represented through the following loss function:

$L=(\Delta s-a)^{2}+\lambda y^{2}$

Where $\Delta s$ is the aggregate fiscal stance of the euro area (i.e. the variation of the structural balance in percent of potential GDP), and $\lambda>0$ is a parameter weighing the stabilization objective relative to the sustainability objective. The loss function is minimized under the following constraint, which links the output gap to structural adjustment:

$y=-\mu \Delta s+\epsilon$

where $\mu>0$ is the aggregate fiscal multiplier and $\varepsilon$ represents exogenous shocks to the output gap. Plugging (2) into (1) yields:

$L=(\Delta s-a)^{2}+\lambda(-\mu \Delta s+\epsilon)^{2}$

The optimal fiscal adjustment $\Delta s$ is the one that minimizes the loss function (3). The first-order condition provides the following optimal rule (the "reaction function"):

$\left(1+\lambda \mu^{2}\right) \Delta s=a+\lambda \mu \epsilon$

Or equivalently:

$\Delta s=a+\lambda \mu y$

Hence the "optimal" structural adjustment is more ambitious when the output gap is positive; symmetrically, it is paced down in case the output gap is negative.

Like the overall fiscal balance, the current account depends positively on the output gap. Denoting by $b$ the current account in percent of GDP, we have:

$b=\tilde{b}-\gamma y$

Where $\gamma>0$, and $\tilde{b}$ is the "underlying" current account, i.e. the current account that would be obtained in the absence of an output gap. ${ }^{27}$ Equivalently, we have:

$y=(\tilde{b}-b) / \gamma$

The reaction function (5) can be re-written accordingly:

$\Delta s=a-\lambda \mu(b-\tilde{b}) / \gamma$

\footnotetext{
${ }^{27}$ See Williamson (1983).
} 
Other things equal, a higher current account will reduce the optimal pace of structural adjustment. Structural adjustment no longer depends on the output gap (as in Equation 5), but on the "currentaccount gap" $b-\tilde{b}$. Like the output gap, the current-account gap raises a number of issues. As a first approximation, it may be calculated as the gap between the observed current account and its trend (over the cycle we have $\tilde{b}=b$, like we have $y=0$ ). However, the current account may be subject to shocks to terms of trade or the real exchange rate, like potential output may be subject to productivity shocks. Sophisticated econometric methods may help to circumvent these problems (see, e.g., Salto and Turini, 2010; Haltmaier, 2014; European Commission, 2015a), but then confidence bands will need to be accounted for.

On the whole, neither (5) nor (8) can be applied mechanically. They should be used as a first pass when the euro area fiscal stance is discussed. If both reaction functions point in opposite directions, then the case may be made for dropping the stabilization objective and setting $\Delta s=a$. However, if both measures point in the same direction, then there may be a case for changing the path of fiscal adjustment, after in-depth analysis is carried out. 